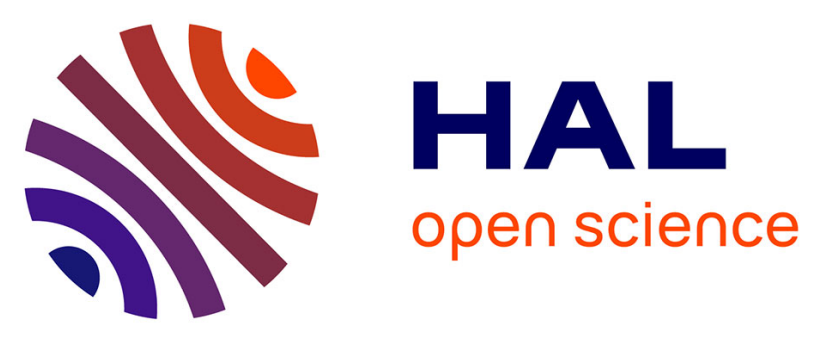

\title{
Investigation of Antioxidant and Elastase Inhibitory Activities of Geum urbanum Aerial Parts, Chemical Characterization of Extracts Guided by Chemical and Biological Assays
}

Marie Schmitt, Abdulmagid Alabdul Magid, Jean-Marc Nuzillard, Jane

Hubert, Nicolas Etique, Laurent Duca, Laurence Voutquenne-Nazabadioko

\section{To cite this version:}

Marie Schmitt, Abdulmagid Alabdul Magid, Jean-Marc Nuzillard, Jane Hubert, Nicolas Etique, et al.. Investigation of Antioxidant and Elastase Inhibitory Activities of Geum urbanum Aerial Parts, Chemical Characterization of Extracts Guided by Chemical and Biological Assays. Natural Product Communications , 2020, 15 (3), pp.1934578X2091530. 10.1177/1934578X20915307 . hal-02880950

\section{HAL Id: hal-02880950 https://hal.univ-reims.fr/hal-02880950}

Submitted on 1 Oct 2020

HAL is a multi-disciplinary open access archive for the deposit and dissemination of scientific research documents, whether they are published or not. The documents may come from teaching and research institutions in France or abroad, or from public or private research centers.
L'archive ouverte pluridisciplinaire HAL, est destinée au dépôt et à la diffusion de documents scientifiques de niveau recherche, publiés ou non, émanant des établissements d'enseignement et de recherche français ou étrangers, des laboratoires publics ou privés. 
Investigation of antioxidant and elastase inhibitory activities of Geum urbanum aerial parts, chemical characterization of extracts guided by chemical and biological assays

Marie Schmitt $^{1 *}$, Abdulmagid Alabdul Magid ${ }^{1}$, Jean-Marc Nuzillard ${ }^{1}$, Jane Hubert ${ }^{1,2}$, Nicolas Etique $^{3}$, Laurent Duca ${ }^{3}$, Laurence Voutquenne-Nazabadioko ${ }^{1 *}$

${ }^{1}$ Université de Reims Champagne Ardenne, CNRS, ICMR UMR 7312, 51097 Reims, France

${ }^{2}$ Current Address: NatExplore SAS, Prouilly, France

${ }^{3}$ Université de Reims Champagne Ardenne, CNRS, MEDyC UMR 7369, 51097 Reims, France

Corresponding Author:

Laurence Voutquenne-Nazabadioko, Université de Reims Champagne Ardenne, CNRS, ICMR UMR 7312, 51097 Reims, France.

Email: laurence.nazabadioko@univ-reims.fr 


\begin{abstract}
This study presents the bio-guided chemical investigation of the hydromethanolic (80\% methanol, v/v) extract of Geum urbanum aerial parts. Liquid-liquid partitioning of this extract in solvents of increasing polarity combined with biological screening showed that the EtOAc soluble fraction was the most active part of the extract. This fraction was chemically profiled by a ${ }^{13} \mathrm{C}$ NMR-based dereplication method, resulting in the identification of fourteen compounds. The dereplication process was followed by the purification of unknown and minor compounds of the EtOAc fraction. A new glycosylated phenol, namely 3-(3,4dihydroxyphenyl)propyl- $\alpha$-L-rhamnopyranoside, together with six known compounds were isolated. Their structures were elucidated by spectroscopic methods including NMR and HRESI-MS. The antioxidant activity of fractions and isolated compounds were evaluated by DPPH and hydroxyl radical scavenging, and by CUPRAC assays. In parallel, their enzyme inhibitory property against human neutrophil elastase was assessed. Four sub-fractions, essentially containing polyphenols and triterpenes, exhibited a significant elastase inhibitory activity and an ellagitannin showed a very high radical scavenging activity.
\end{abstract}

\title{
Keywords
}

Geum urbanum, ellagitanins, phenols, NMR dereplication, antioxidant, elastase. 
Skin aging is a complex biological process mainly characterized by wrinkle formation, uneven pigmentation, darkening, thinning, and roughening of the skin. This could be caused by intrinsic (genetically determined) or extrinsic (mediated by exposure to UV radiation and to toxic compounds) mechanisms. One of the underlying mechanisms of these processes is an excessive oxidative stress, which is probably the single most harmful contributor to skin aging, leading to loss of cells and to extracellular matrix degradation as the most prominent features of chronologically aged skin. Oxidative stress results from an imbalance between reactive oxygen species production and antioxidative defense. ${ }^{1}$ Prevention of these dynamic processes is a major issue for dermo-cosmetics and substantial efforts are being made to discover new protective ingredients. ${ }^{2,3}$ Plant extracts can contain high concentration of phenolic compounds, carotenoids, terpenoids, etc. able to inhibit free radicals and therefore to slow down skin aging. ${ }^{4,5}$ The antioxidant potency of phenolic compounds (phenolic acids, flavonoids, anthocyanidins, tannins) can be easily determined by chemical tests such as DPPH assay, the ferric reducing/antioxidant power (FRAP) assay, the ABTS assay, and the cupric ion reducing antioxidant capacity (CUPRAC) assay. ${ }^{4}$ Phenolics have also been reported as effective compounds in matrix remodeling activation through inhibition of elastases, ${ }^{6}$ a class of proteases highly involved in aging.

In the continuation of our search for local plants with anti-aging properties, ${ }^{7,8}$ we were interested by Geum urbanum L., a perennial herbaceous plant belonging to the Rosaceae family. The genus Geum encompasses about 70 species distributed in temperate regions all over the world. G. urbanum is native to humid woods of Europe and Asia ${ }^{9}$ and is a common species in France, especially in cool places such as hedges and undergrowth. ${ }^{10}$ Infusions from the roots and rhizomes of $G$. urbanum have been traditionally used in folk medicine in the treatment of acute diarrhea and as astringent agent for inflammations of the mucosa and gums and for treatment of hemorrhoids. ${ }^{9,11}$ Previous works have shown that plants species belonging to the Geum genus produce ellagitannins, gallotannins, flavonoids, terpenoids and phenylpropanoids. ${ }^{12,13,14}$ Ellagitannins (tellimagrandin, stachyurin, casuarynin, gemin A, and ellagic acid derivatives), procyanidins (procyanidin $B_{3}$, procyanidin $C_{2}$, and catechin derivatives), gallic acid and its derivatives, steroids and triterpenoids were isolated from the roots of G. urbanum..$^{11,15,16,17,18}$ To our knowledge, the antioxidant and antielastase potency of G. urbanum aerial parts and their relation to chemical composition have not been reported. Recently, the radical scavenging activity of extracts and fractions obtained from aerial and underground parts of G. urbanum were investigated and the EtOAc fractions from roots and 
aerial parts were found to be the most active, but only the EtOAc extract of the roots were investigated. ${ }^{15}$

Thus, the aim of the present study was to investigate the antioxidant and elastase inhibitory activities of extracts, fractions and isolated compounds obtained from the aerial parts of $G$. urbanum. A ${ }^{13} \mathrm{C}$ NMR-based dereplication methodology combined to a bio-guided fractionation and purification procedure was used to identify some of its metabolites.

\section{Results and discussion}

A hydromethanolic ( $80 \%$ methanol, v/v) extract (hereafter referred to as GUM) was obtained from G. urbanum aerial parts. Its solution in water was fractionated by extraction with a series of solvents of increasing polarity, resulting in a dichloromethane fraction (DCMF), ethyl acetate fraction (EAF), and $n$-butanol fraction $(n-\mathrm{BF})$. The free radical scavenging activities of GUM and obtained fractions were determined by the DPPH and hydroxyl radical assays whereas their cupric reducing capacity was evaluated by the CUPRAC assay. In addition, their ability to inhibit human neutrophil elastase activity was tested. The results are shown in Table 1. As previously described for roots and aerial parts of G. urbanum, ${ }^{15}$ the EAF had the best antioxidant activities. $n$-BF exhibited the best DPPH scavenging activity $\left(\mathrm{IC}_{50}<12.5\right.$ $\mu \mathrm{g} / \mathrm{mL}$ ) followed by EAF and GUM ( $\mathrm{IC}_{50} 14.7 \mu \mathrm{g} / \mathrm{mL}$ and $21.8 \mu \mathrm{g} / \mathrm{mL}$, respectively). The hydroxyl radicals scavenging activity was better for EAF and GUM (IC $50142.7 \mu \mathrm{g} / \mathrm{mL}$ and $174.5 \mu \mathrm{g} / \mathrm{mL}$, respectively). For all extracts, a substantial cupric ion reducing capacity was observed ( $\mathrm{IC}_{50}<2.0 \mu \mathrm{g} / \mathrm{mL}$ ), but lower than the one of trolox, used as positive standard. In addition, a very good elastase inhibitory activity was observed for DCMF and $n$-BF (IC 5017.6 $\mu \mathrm{g} / \mathrm{mL}$ and $14.3 \mu \mathrm{g} / \mathrm{mL}$, respectively), but EAF showed the best activity ( IC $_{50} 6.0 \mu \mathrm{g} / \mathrm{mL}$ ), identical to quercetin used as positive standard. The EAF having interesting biological activities, in both antioxidant and anti-elastase assays, was chemically investigated through a bioassay-guided isolation strategy in order to tentatively determine the active constituents.

The major compounds of EAF were identified using a dereplication method ${ }^{19}$ combining Centrifugal Partition Chromatography (CPC), NMR analysis, clustering of NMR peak emergence profiles, and data base search, without purification of individual components. The CPC fractionation of EAF was performed with the biphasic solvent system $\mathrm{MtBE} / \mathrm{CH}_{3} \mathrm{CN} /$ water $(3 / 3 / 4, \mathrm{v} / \mathrm{v} / \mathrm{v})$ to afford eleven sub-fractions $\left(\mathrm{EAF}_{1-11}\right)$. After ${ }^{13} \mathrm{C} \mathrm{NMR}$ analyses of $\mathrm{EAF}_{1-11}$, all spectra of the fraction series were processed and submitted to Hierarchical Clustering Analysis (HCA) for the recognition of similarity between emergence 
profiles of ${ }^{13} \mathrm{C}$ NMR peaks throughout the fractionation process. In this way, ${ }^{13} \mathrm{C} \mathrm{NMR}$ signals belonging to the same compounds were grouped to build "chemical shift clusters" represented in the heat map drawn in Fig. 1. As a result, 13 major chemical shift clusters corresponding to the major metabolites of the EAF (Fig. 1), colored in yellow, were revealed by the heat map. An in-house database containing predicted chemical shift values of natural metabolites was used to identify the metabolites from the chemical shifts within clusters. Cluster 1 in fraction $\mathrm{EAF}_{10}$ was assigned to saccharose and $\beta$-fructose. The identification of saccharose and $\beta$-fructose was easily confirmed by checking HSQC, HMBC and COSY data of fraction $\mathrm{EAF}_{10}$ and by comparison with literature data. ${ }^{20}$ Similarly, clusters 2 to 11 were identified as ellagic acid and gallic $\operatorname{acid}^{21}$ (clusters 2, 2' and 2"; fraction $\mathrm{EAF}_{6}$ ), a mixture of 6$O$ - $E$-caffeoyl- $\beta$-D-glucopyranose ${ }^{22}$ and malic acid ${ }^{20}$ (clusters 3 and 7 ; fractions $\mathrm{EAF}_{2-8}$ ), succinic $\operatorname{acid}^{23}$ (cluster 4; fractions $\mathrm{EAF}_{3-4}$ ), dotorioside $\mathrm{II}^{24}$ (cluster 5; fractions $\mathrm{EAF}_{3-4}$ ), tormentic $\operatorname{acid}^{25}$ (cluster 6; fraction $\mathrm{EAF}_{1}$ ), caffeic $\operatorname{acid}^{26}$ (cluster 7, fraction $\mathrm{EAF}_{7}$ ), ellagic acid pentoside (cluster 8; fractions $\mathrm{EAF}_{3-5}$ ), (+)-catechin $(\mathbf{2})^{27}$ (cluster 10; fractions $\mathrm{EAF}_{2-3}$ ), and 3,3'-di-O-methylellagic acid ${ }^{28}$ (cluster 11; fraction $\mathrm{EAF}_{3}$ ). For the fractions $\mathrm{EAF}_{4-5}$, the database proposed a 3-(3,4-dihydroxyphenyl)propyl-glycoside (1), which could not be identified unambiguously (cluster 9).

Fractions $\mathrm{EAF}_{1-7}$ containing the phenolic compounds identified by dereplication were further screened for their antioxidant and elastase inhibitory activities. As shown in Table 1, all tested fractions presented very good antioxidant activities, revealed by DPPH and CUPRAC assays. EAF $_{1-7}$ showed also a significant elastase inhibitory activity, in particular $\mathrm{EAF}_{1-4}\left(\mathrm{IC}_{50} 2.1 \mu \mathrm{g} / \mathrm{mL}, 2.9 \mu \mathrm{g} / \mathrm{mL}, 5.1 \mu \mathrm{g} / \mathrm{mL}\right.$ and $8.0 \mu \mathrm{g} / \mathrm{mL}$, respectively). The most active fractions $\mathrm{EAF}_{2-4}$ and $\mathrm{EAF}_{7}$ were further purified using semi-preparative HPLC, to identify the compounds responsible of the activities, and afforded an undescribed glycosylated phenol (1) and six known compounds $(\mathbf{2}-\mathbf{7})$. The known compounds were identified as (+) catechin (2), ${ }^{27}$ 1-(4-hydroxy-3-methoxyphenyl)-1,2,3-propanetriol $\quad$ (guaiacylglycerol) (3), ${ }^{29}$ tellimagrandin II (4), ${ }^{30}$ 3-O-methylellagic acid-4'- $O$ - $\beta$-D-xylopyranoside (5), ${ }^{31}$ 2,3-dihydro-3hydroxymethyl-7-methoxy-2-(4'-hydroxyphenyl-3'-methoxy)-5-benzofuranpropanol-4'-O- $\alpha$ L-rhamnopyranoside (icariside E4) $(6)^{32}$, and gemin A (7) ${ }^{33}$ (Fig. 2) by comparison of physical data with literature values and from spectroscopic evidence.

Compound 1 was as yellowish-brown solid obtained in mixture with compound $\mathbf{3}$ (50/50 based in ${ }^{1} \mathrm{H}$ NMR). The spectral analysis of the mixture showed for $\mathbf{1}$ a molecular formula $\mathrm{C}_{15} \mathrm{H}_{22} \mathrm{O}_{7}$, deduced from its negative ionization HR-ESI-MS analysis $(\mathrm{m} / \mathrm{z} 313.1284$, 
$\left.[\mathrm{M}-\mathrm{H}]^{-}\right)$. The ${ }^{1} \mathrm{H}$ and ${ }^{13} \mathrm{C}$ NMR spectra of 1 presented resonances corresponding to aromatic and glycosidic protons and carbons. The ${ }^{1} \mathrm{H}$ NMR spectrum of 1 showed three signals accounting for one proton each at $\delta_{\mathrm{H}} 6.65(\mathrm{~d}, J=2.0 \mathrm{~Hz}), 6.77(\mathrm{~d}, J=8.2 \mathrm{~Hz})$ and $6.59(\mathrm{dd}, J$ $=8.2,2.0 \mathrm{~Hz}$ ), due to $\mathrm{H}-2^{\prime}, \mathrm{H}-5^{\prime}$ and $\mathrm{H}-6^{\prime}$ in a tri-substituted aromatic ring. These protons were correlated in the HSQC spectrum with their aromatic carbon atoms at $\delta_{\mathrm{C}} 116.4,116.3$ and 121.0, respectively. In addition, six protons at $\delta_{\mathrm{H}} 3.28(1 \mathrm{H}, \mathrm{m}) / 3.57(1 \mathrm{H}, \mathrm{m}), 1.76(2 \mathrm{H}$, quin, $J=6.9 \mathrm{~Hz})$ and $2.50(1 \mathrm{H}, \mathrm{q}, J=7.3 \mathrm{~Hz}) / 2.52(1 \mathrm{H}, \mathrm{q}, J=7.2 \mathrm{~Hz})$, due respectively to the protons $\mathrm{H}-1, \mathrm{H}-2$ and $\mathrm{H}-3$ of an alkyl chain correlated in the HSQC spectrum to their alkyl carbon atoms at $\delta_{\mathrm{C}} 66.2,31.1$ and 31.1 , respectively. Complete assignment of the remaining resonances of the aglycone in the ${ }^{13} \mathrm{C}$ NMR spectrum of $\mathbf{1}$ was achieved by analysis of the HMBC data which confirmed the presence of a diphenol linked to an alkyl chain. The linkage site of the alkyl chain was determined by analysis of HMBC spectrum. The correlation between $\mathrm{H}-3\left(\delta_{\mathrm{H}} 2.50 / 2.52\right)$ and C-1' of the aromatic ring $\left(\delta_{\mathrm{C}} 134.7\right)$ indicated the position of alkyl chain on the diphenol. A full list of the corresponding assignments is given in experimental section. Furthermore, an anomeric proton resonance corresponding to $O$-linked sugar was observed in the ${ }^{1} \mathrm{H}$ NMR spectrum as doublet at $\delta_{\mathrm{H}} 4.53\left(J=1.9 \mathrm{~Hz}, \mathrm{H}-1^{\prime \prime}\right)$ and the signal of his corresponding ${ }^{13} \mathrm{C}$ NMR carbon was at $\delta_{\mathrm{C}} 100.3\left(\mathrm{C}-1^{\prime \prime}\right)$. A methyl signal at $\delta_{\mathrm{H}}$ $1.14\left(\mathrm{~d}, J=6.2 \mathrm{~Hz}, \mathrm{H}-6^{\prime \prime}\right)$ and $\delta_{\mathrm{C}} 16.6$ (C-6") indicated a 6-desoxy-hexose. Analysis of COSY correlations allowed us to assign complete spin systems of an $\alpha$-L-rhamnopyranose ${ }^{34}$ (see experimental). The $\alpha$-configuration of rhamnose deduced from the small ${ }^{3} J_{\mathrm{H}-1, \mathrm{H}-2}$ value was confirmed by the chemical shift of C-5 $\left(\delta_{\mathrm{C}} 68.4\right){ }^{35}$ The HMBC correlation between H-1" $\left(\delta_{\mathrm{H}}\right.$ 4.53) and $\mathrm{C}-1$ of the aglycone $\left(\delta_{\mathrm{C}} 66.2\right)$ indicated the position of sugar on the alkyl chain. Therefore, the structure of $\mathbf{1}$ was elucidated as 3-(3,4-dihydroxyphenyl)propyl- $\alpha$-Lrhamnopyranoside, as shown in Fig. 2.

Isolated compounds 2, 5, 6 and 7 were evaluated only for their antioxidant activity, using the DPPH scavenging assay, due to their low available mass. Compounds $\mathbf{1}$ and $\mathbf{3}$ were isolated in a mixture, so their activities could not be evaluated. The biological activity of compounds 3 and 4 was discussed based on literature data. As summarized in Table 1, compounds 2, 5, 6 and 7 presented a very good antioxidant activity ( $\mathrm{IC}_{50}<23.0 \mu \mathrm{M}$ ), with compound 7 achieving noticeably at best ( $\mathrm{IC}_{50} 2.7 \mu \mathrm{M}$ ). According to literature, compounds $\mathbf{3}^{36}$ and $\mathbf{4}^{37}$ showed a moderate DPPH scavenging activity (3: $\mathrm{IC}_{50} 133.2 \mu \mathrm{M}, \mathbf{4}: \mathrm{IC}_{50} 50.9$ $\mu \mathrm{M}$ ), while catechin (2) showed good antioxidant activities on DPPH (IC $5018.3 \mu \mathrm{M})$, FRAP ( IC $_{50} 13.4 \mu \mathrm{M}$ ), and ABTS ( IC $_{50} 3.8 \mu \mathrm{M}$ ) assays. ${ }^{38}$ The antioxidant activities of caffeic acid 
(cluster 7), gallic acid (cluster 2) and ellagic acid are well known with $\mathrm{IC}_{50} 58.8,10.6$ and 3.9 $\mu \mathrm{M}$ on DPPH assay, respectively. ${ }^{39,40,41}$ The radical scavenging activity on DPPH of dotorioside II (cluster 5) and tormentic acid (cluster 6) were also previously evaluated and showed to be very low. ${ }^{42,43}$ The very high activity of compound $\mathbf{7}$ is probably due to the presence of several gallic acid units containing numerous aromatic hydroxyl groups known to be related to antioxidant activity. ${ }^{40,44}$ Indeed, the phenols/polyphenols have the capacity to lose one or more $\mathrm{H}^{+}$ions and thus to trap the free radicals in the ortho and para position of the donor hydroxyl group. In the case of a polyphenol such as catechol, the two hydroxyl groups provide two ortho sites and two para sites, which allows an efficient trapping of free radicals. The antioxidant power of compound 7 being seventeen times higher than that of compound 4, we can suggest that the more gallic acid units in an ellagic tannins, the higher its activity.

\section{Conclusions}

The present study reports for the first time the isolation and identification of nineteen secondary metabolites including ellagic tannins, ellagic acids derivatives, phenolic acids, glycosides derivatives and triterpenes from aerial parts of Geum urbanum. Our studies demonstrated that EtOAc fractions (EAF) were characterized by the highest anti-elastase and antiradical activity among all prepared fractions. For this reason, we isolated individual constituents of the EAF fraction and evaluated their contribution to the observed activities. We isolated and identified a new glycosylated phenol, together with six compounds.

From a chemotaxonomic viewpoint, catechin (2) was isolated earlier in G. urbanum $^{15}$ and G. iranicum. ${ }^{45}$ Gemin A (7) was previously reported from G. japonicum, ${ }^{33}$ G. aleppicum Jacq. and G. calthifolium var. nipponicum. ${ }^{46}$ Among the compounds elucidated by dereplication, 6-O-E-caffeoyl- $\beta$-D-glucopyranose, succinic acid and 3-(3,4dihydroxyphenyl)propyl-glycoside are reported here for the first time in the genus Geum. Eight compounds were previously isolated from G. urbanum roots: tormentic acid, ${ }^{15}$ ellagic acid pentoside, ${ }^{16}$ ellagic acid, gallic acid, caffeic acid, (+)-catechin, ${ }^{15,17}$ malic acid, ${ }^{18}$ and dotorioside II. ${ }^{11}$ The three other compounds were already known in the genus Geum. ${ }^{28,45,47}$ Two compounds previously isolated in G. urbanum roots, ${ }^{15,16}$ the ellagic tannins $\mathbf{4}$ and $\mathbf{7}$, could be considered as chemotaxonomic markers of this species.

Regarding biological activities, four sub-fractions, essentially containing polyphenols, presented a significant elastase inhibitory activity and, among the identified compounds, 
phenolics 2, 5, 6 and 7 showed high antioxidant property. These tests have highlighted the antioxidant activity of polyphenols and more particularly catechin (2) and gemin A (7). The EAF and the polyphenols identified from G. urbanum are promising compounds for applications in the dermo-cosmetic field due to their very interesting antioxidant and antielastase activities.

\section{Experimental}

\section{General experimental procedures}

1D- and 2D-NMR spectra were recorded at $298 \mathrm{~K}$ in $\mathrm{CH}_{3} \mathrm{OH}-d_{4}$ or DMSO- $d_{6}$ on a Bruker AvanceIII-600 spectrometer (Karlsruhe, Germany) $\left({ }^{1} \mathrm{H}\right.$ at $600 \mathrm{MHz}$ and ${ }^{13} \mathrm{C}$ at $151 \mathrm{MHz}$ ) equipped with a $5 \mathrm{~mm}$ TCI cryoprobe. The Bruker TopSpin 3.6 software was used for NMR data acquisition and processing. HR-ESI-MS spectra were recorded on a Micromass Q-TOF micro instrument (Manchester, UK). Mass spectra were recorded in the negative ionization mode in the $m / z$ range 100-2000, with a mass resolution of 20.000 and an acceleration voltage of $0.7 \mathrm{kV}$. Semi-preparative HPLC purification was carried out on a Dionex apparatus equipped with an ASI-100 automated sample injector, a STH 585 column oven, a P580 pump, and a UVD 340S diode array detector, all driven by the Chromeleon ${ }^{\circledR}$ software version 6.8 . Analytical HPLC experiments were performed using a Thermofisher Ultimate 3000 (Thermo Fischer Scientific, Villebon-sur-Yvette, France), equipped with a four ways pump LPG 3400 SD, an automatic injector WPS 3000 SL, a UV/visible diode array detector 3000, and the Chromeleon ${ }^{\circledR}$ software version 6.8. A prepacked $\mathrm{C}_{18}$ column (Interchim, $250 \times 10 \mathrm{~mm}, 5 \mu$ ) was employed for semi-preparative HPLC. The mobile phase was composed of $\mathrm{H}_{2} \mathrm{O}$ acidified with TFA $(0.025 \%)$ and $\mathrm{CH}_{3} \mathrm{CN}$ with a flow rate of $5 \mathrm{~mL} / \mathrm{min}$ and the chromatograms were monitored at 205, 254, 300 and $360 \mathrm{~nm}$. A prepacked $\mathrm{C}_{18}$ column Uptisphere Strategy $\mathrm{C}_{18}$ (Interchim, $250 \times 4.6 \mathrm{~mm}, 5 \mu$ ) was used for analytical HPLC and the mobile phase contained $\mathrm{H}_{2} \mathrm{O}$ with TFA $(0.025 \% \mathrm{v} / \mathrm{v})$ and $\mathrm{CH}_{3} \mathrm{CN}$. A gradient elution method was applied, from $5 \%$ to $80 \%$ of $\mathrm{CH}_{3} \mathrm{CN}$ in $30 \mathrm{~min}$ with a flow rate of $1 \mathrm{~mL} / \mathrm{min}$ and the chromatograms were monitored at 205, 254, 300 and $360 \mathrm{~nm}$. Thin-layer chromatography (TLC) was carried out on silica gel $60 \mathrm{~F}_{254}$ pre-coated aluminum plates (0.2 mm, Merck), using $\mathrm{CHCl}_{3} / \mathrm{MeOH} / \mathrm{H}_{2} \mathrm{O}$ $(14 / 6 / 1, \mathrm{v} / \mathrm{v} / \mathrm{v})$ as mobile phase. The compounds were visualized under UV light (254 and 366 $\mathrm{nm}$ ) after high-performance thin-layer chromatography (HPTLC, CAMAG TLC Visualizer 2)

and sprayed with $50 \% \mathrm{H}_{2} \mathrm{SO}_{4}$ followed by heating. A FLUOstar Omega spectrophotometer (BMG LABTECH) was used for absorbance measurement in antioxidant assays. An Infinite 
F200 PRO spectrofluorimeter (Tecan, Lyon, France) was used for measuring fluorescence during anti-elastase assays.

\section{Plant material}

The aerial parts of Geum urbanum L. (Rosaceae) were collected in Châlons-sur-Vesle (Northeastern part of France: $49^{\circ} 2167^{\prime} \mathrm{N}, 4^{\circ} 05^{\prime} \mathrm{E}$ ) in July 2016, authenticated by Dr. Abdulmagid Alabdul Magid and dried at room temperature. A voucher specimen (MA-GU2016-07) was deposited at the Herbarium of the Botanic Laboratory-Faculty of Pharmacy, University of Reims Champagne-Ardenne.

\section{Extraction and isolation}

The dried and powdered G. urbanum aerial parts (300 g) were macerated in $\mathrm{MeOH} / \mathrm{water}$ $(4 / 1, v / v, 3 \times 3 \mathrm{~L}, 24 \mathrm{~h})$ at room temperature. The macerate was concentrated to about $1 \mathrm{~L}$ at $40{ }^{\circ} \mathrm{C}$ under vacuum. An aliquot of the aqueous solution $(100 \mathrm{~mL})$ was evaporated to dryness to obtain the GUM extract (2.6 g). The aqueous solution (1 L) of GUM was successively extracted with dichloromethane $(3 \times 750 \mathrm{~mL})$, ethyl acetate $(3 \times 750 \mathrm{~mL})$ and $n$-butanol $(3 \times$ $750 \mathrm{~mL})$, then dried under reduced pressure to yield DCMF $(6.1 \mathrm{~g}), \mathrm{EAF}(6.2 \mathrm{~g})$ and $n$-BF (24.2 g) extracts, respectively and a water-soluble part (29.2 g).

\section{Centrifugal partition chromatography}

Centrifugal partition chromatography (CPC) fractionation was carried out on a lab-scale FCPE300® column of 303 mL inner volume (Rousselet Robatel Kromaton, Annonay, France) made of 7 circular partition disks and engraved with a total of 231 partition twin-cells $(\approx 1 \mathrm{~mL}$ per twin cell). The liquid phases were pumped by a KNAUER Preparative 1800 V7115 pump (Berlin, Germany). The column was coupled on-line with a UVD $170 \mathrm{~S}$ detector set at 210, 254, 280 and $366 \mathrm{~nm}$ (Dionex, Sunnivale, CA, USA). Fractions of $20 \mathrm{~mL}$ were collected by a Pharmacia Superfrac collector (Uppsala, Sweden). The solvent system was $\mathrm{MtBE} / \mathrm{CH}_{3} \mathrm{CN} /$ water $(3 / 3 / 4, \mathrm{v} / \mathrm{v} / \mathrm{v})$. The column rotation speed was set at $1200 \mathrm{rpm}$ and the flow rate at $20 \mathrm{~mL} / \mathrm{min}$. EAF (1.5 g injected mass) was dissolved in $15 \mathrm{~mL}$ of a mixture of both lower phase $(10 \mathrm{~mL})$ and upper phase $(5 \mathrm{~mL})$. The upper phase of the biphasic solvent system was pumped for $85 \mathrm{~min}$ in the ascending mode. The stationary phase was then extruded by pumping the organic phase in the descending mode at $20 \mathrm{~mL} / \mathrm{min}$. Fractions of 20 
$\mathrm{mL}$ were collected over the whole process. All fractions were analyzed by TLC and HPLC and then pooled to yield fractions $\mathrm{EAF}_{1-11}$.

\section{NMR analysis and dereplication of the metabolites}

The structures and names of metabolites already reported in the genus Geum $(\mathrm{n}=50)$ were collected from articles available in the scientific literature. The predicted ${ }^{13} \mathrm{C}$ NMR chemical shifts of each one was then stored into a local database already comprising 3038 structures of natural compounds (NMR Workbook Suite 2012, ACD/Labs, Ontario, Canada). In a second step, all CPC fractions were dried under vacuum and an aliquot (up to $20 \mathrm{mg}$ when possible) was dissolved in $600 \mu \mathrm{L}$ of DMSO- $d_{6}$ and analyzed by ${ }^{13} \mathrm{C}$ NMR. A standard zgpg pulse sequence was used with an acquisition time of $0.9 \mathrm{~s}$ and a relaxation delay of $3 \mathrm{~s}$. For each sample, 1024 scans were added to obtain a satisfactory signal-to-noise ratio. The spectral width was $240 \mathrm{ppm}$ and the receiver gain was set to the highest possible value. Spectra were then manually phased, baseline corrected, and calibrated on the central resonance of DMSO$d_{6}(\delta 39.8 \mathrm{ppm})$. The last step consisted in the binning of all ${ }^{13} \mathrm{C}$ NMR signals followed by the visualization of the whole dataset as a heat map. For this purpose, the absolute intensities of all ${ }^{13} \mathrm{C}$ NMR signals detected in the spectra of the fraction series were automatically collected and each resulting peak list was stored as a text file. The binning step was performed by a locally developed computer script written in Python language. Its principle was to divide the ${ }^{13} \mathrm{C}$ spectral domain (from 0 to $240 \mathrm{ppm}$ ) into chemical shift intervals (or bins) of identical width $(\Delta \delta=0.2 \mathrm{ppm})$, and to associate the absolute intensity of each peak to the corresponding bin. The resulting table was imported into the PermutMatrix version 1.9.3 software (LIRMM, Montpellier, France) and submitted to Hierarchical Clustering Analysis (HCA) for data visualization. The chemical shift clusters regrouped with the HCA were then submitted to database search for compound identification. Additional 1D and 2D NMR experiments ( ${ }^{1} \mathrm{H}$ NMR, HSQC, HMBC, and $\left.{ }^{1} \mathrm{H}-{ }^{1} \mathrm{H}-\mathrm{COSY}\right)$ were recorded and analyzed in order to confirm the structures of the identified compounds.

\section{HPLC purification of EAF}

Fraction $\mathrm{EAF}_{2}$ was subjected to semi-preparative HPLC using the gradient system (15-40\% $\left.\mathrm{CH}_{3} \mathrm{CN}, 30 \mathrm{~min}\right)$ to yield compounds $2\left(\mathrm{t}_{\mathrm{R}}=5.9 \mathrm{~min}, 3.8 \mathrm{mg}\right), 4\left(\mathrm{t}_{\mathrm{R}}=9.5 \mathrm{~min}, 4.3 \mathrm{mg}\right)$ and the mixture of 1 and $3\left(t_{R}=20.2 \mathrm{~min}, 5.1 \mathrm{mg}\right)$. Fractions $\mathrm{EAF}_{3-4}$ were purified by semi-prep. HPLC with gradient system (10-40\% $\left.\mathrm{CH}_{3} \mathrm{CN}, 30 \mathrm{~min}\right)$ to yield compounds $\mathbf{1}$ and $\mathbf{3}$ in mixture 
$\left(t_{R}=12.6 \mathrm{~min}, 2.7 \mathrm{mg}\right), 5\left(t_{R}=13.4 \mathrm{~min}, 3.8 \mathrm{mg}\right)$ and $\mathbf{6}\left(\mathrm{t}_{\mathrm{R}}=13.8 \mathrm{~min}, 3.7 \mathrm{mg}\right)$. Fraction $\mathrm{EAF}_{7}$ was purified by semi-prep. HPLC with gradient system $\left(10-25 \% \mathrm{CH}_{3} \mathrm{CN}, 20 \mathrm{~min}\right)$ to yield compound $7\left(\mathrm{t}_{\mathrm{R}}=11.2 \mathrm{~min}, 4 \mathrm{mg}\right)$.

\subsection{3-(3,4-Dihydroxyphenyl)propyl- $\alpha$-L-rhamnopyranoside (1)}

Yellowish-brown solid; ${ }^{1} \mathrm{H}$ NMR (600 MHz, CD 3 OD, supplemental data, figure S1) $3.28(1 \mathrm{H}$, m, H-1a), 3.57 (1H, m, H-1b), $1.76(1 \mathrm{H}$, quin, J=6.9 Hz, H-2a), 2.50 (1H, qd, J=7.3 Hz, H3a), 2.52 (1H, qd, J=7.2 Hz, H-3b), 6.65 (1H, d, J=2.0 Hz, H-2'), 6.77 (1H, d, J=8.2 Hz, H-5'), 6.59 (1H, dd, $J=8.2,2.0 \mathrm{~Hz}, \mathrm{H}-6$ '), 4.53 (1H, d, $J=1.9 \mathrm{~Hz}, \mathrm{H}-1 "), 3.69$ (1H, dd, $J=3.4,1.9 \mathrm{~Hz}$, H-2"), 3.55 (1H, dd, J=9.4,3.4 Hz, H-3"), 3.26 (1H, t, J=9.4 Hz, H-4"), 3.48 (1H, m, H-5"), $1.14(3 \mathrm{H}, \mathrm{d}, J=6.2 \mathrm{~Hz}, \mathrm{H}-6 ") ;{ }^{13} \mathrm{C}$ NMR $\left(125 \mathrm{MHz}, \mathrm{CD}_{3} \mathrm{OD}\right.$, supplemental data, figure S2) 66.2 (C-1), 31.1 (2), 31.2 (3), 134.7 (1'), 116.4 (C-2'), 143.7 (C-3'), 141.6 (C-4'), 116.3 (C-5'), 121.0 (C-6'), 100.3 (C-1"), 70.9 (C-2"), 71.0 (C-3"), 72.6 (C-4"), 68.4 (C-5"), 16.6 (C-6") ; HRESI-MS (negative-ion mode) $m / z: 313.1284[\mathrm{M}-\mathrm{H}]^{-}$(calculated for $\mathrm{C}_{15} \mathrm{H}_{21} \mathrm{O}_{7}, 313.1287$ ).

\section{DPPH radical scavenging activity}

Extracts, fractions and compounds 2, 5, 6 and 7 were evaluated for their DPPH radical scavenging activity according to a recently published procedure. ${ }^{8}$ Samples were prepared at concentrations of 200,100, 50, 25, 12.5 and $6.25 \mu \mathrm{g} / \mathrm{mL}$. Ascorbic acid and quercetin were used as positive controls. All the tests were conducted in triplicate for each concentration.

\section{Hydroxyl radical scavenging activity}

Extracts and fractions were evaluated for their hydroxyl radical scavenging activity at various concentrations, ranging from 1330 to $41.56 \mu \mathrm{g} / \mathrm{mL}$, according to a recently published procedure. $^{8}$

\section{Power cupric ion reducing (CUPRAC) assay}

Extracts and fractions were tested for their cupric ion reducing ability. The cupric ion reducing activity (CUPRAC) was determined according to a published method. ${ }^{48}$ Samples were prepared at concentrations of $572,286,143,71.5,35.75,17.87$ and $8.94 \mu \mathrm{g} / \mathrm{mL}$ and dissolved in $\mathrm{H}_{2} \mathrm{O} / \mathrm{DMSO}(9 / 1, \mathrm{v} / \mathrm{v})$. A volume of $45 \mu \mathrm{L}$ of each diluted sample was added to a premixed reaction mixture containing $\mathrm{CuCl}_{2}(90 \mu \mathrm{L}, 10 \mathrm{mM})$, freshly prepared neocuproine $\left(90 \mu \mathrm{L}, 7.5 \mathrm{mM}\right.$, dissolved in distilled water and ethanol in proportion 8/2, (v/v) and $\mathrm{NH}_{4} \mathrm{Ac}$ 
buffer $(90 \mu \mathrm{L}, 1 \mathrm{M}, \mathrm{pH} 7.0)$. Similarly, a blank test mixture was prepared by adding sample solution $(45 \mu \mathrm{L})$ to premixed reaction mixture $(270 \mu \mathrm{L})$ without $\mathrm{CuCl}_{2}$. The reaction proceeded for $30 \mathrm{~min}$ at room temperature on a 96-well microplate and the absorbance was then read at $450 \mathrm{~nm}$. Ascorbic acid, quercetin and trolox were used as positive controls. The power cupric ion reducing was calculated as follows: $\left[1-A_{0} /\left(A_{1}-A_{2}\right)\right] \times 100$, where $A_{0}$ is absorbance of the control (without sample), $A_{1}$ is absorbance in the presence of the sample and $A_{2}$ is absorbance of the blank. All the tests were conducted in triplicate and $\mathrm{IC}_{50}$ were determined by interpolation of concentration versus inhibition curves obtained by a MSExcel calculation sheet.

\section{Elastase enzyme assay}

Extracts and fractions were evaluated for their ability to inhibit Human Leukocyte Elastase (HLE) (Merck Biosciences). Tests were performed in 96-well microplates pre-coated with $1 \%$ Bovine Serum Albumin. HLE $(0.8 \mu \mathrm{M})$ was incubated for $1 \mathrm{~h}$ at $27^{\circ} \mathrm{C}$ in Tris buffer $(50 \mathrm{mM}$ Tris- $\mathrm{HCl} \mathrm{pH} 7.5$ containing $500 \mathrm{mM} \mathrm{NaCl}$ ) containing 0.1 to $1000 \mu \mathrm{g} / \mathrm{mL}$ of tested sample. Pure solvent was used as a control sample. The assay was initiated by adding HLE fluorogenic substrate MeOSuc-Ala-Ala-Pro-Val-AMC $\left(\lambda_{\mathrm{exc}}=380 \mathrm{~nm} / \lambda_{\mathrm{em}}=460 \mathrm{~nm}\right)$ at a final concentration of $80 \mu \mathrm{M}$. The rate of substrate cleavage was measured in triplicate for each sample concentration with one measurement per minute for $60 \mathrm{~min}$. HLE activity was calculated according to: $\%$ HLE activity $=\left(\right.$ Slope $\left._{\text {sample }} \mathrm{x} 100\right) /$ Slope $_{\text {control }}$, where slope sample $_{\text {and }}$ slope $_{\text {control }}$ are the slope of the curve in the graph of fluorescence intensity versus time. The $\mathrm{IC}_{50}$ values were calculated by non-linear regression analysis with the Graphpad software (La Jolla, USA).

\section{Acknowledgements}

Dr. Marie Schmitt gratefully acknowledges ICMR and MEDyC laboratories as well as URCA PlAneT platform (University Reims Champagne-Ardenne) for giving the possibility to perform all the necessary manipulations for the realization of this publication.

\section{Declaration of Conflicting Interests}

The authors declare no conflict of interest.

\section{Funding}


The authors are grateful to Grand Est region in France and EU-program FEDER for their financial support of this thesis CHAVIC project.

\section{Supplemental Material}

Supplemental material for this article is available online.

\section{References}

1. Sundaram IK, Sarangi DD, Sundararajan V, George S, Mohideen SS. Poly herbal formulation with anti-elastase and anti-oxidant properties for skin antiaging. BMC Comp. Alter. Med. 2018;18:33.

2. Pandel R, Poljsak B, Godic A, Dahmane R. Skin photoaging and the role of antioxidants in its prevention. ISRN Dermatol. 2013;2013:1-11.

3. Sharafzadeh S. Medicinal plants as anti-ageing materials: A review. Glob. J. Med. Plant Res. 2013;1(2):234-236.

4. Fierascu RC, Ortan A, Fierascu IC, Fierascu I. In vitro and in vivo evaluation of antioxidant properties of wild-growing plants. A short review. Current Opinion in Food Science. 2018;24:1-8.

5. Mukherjee PK, Maity N, Nema NK, Sarkar BK. Bioactive compounds from natural resources against skin aging. Phytomedicine. 2011;19:64-73.

6. Xu GH, Ryoo IJ, Kim YH, Choo SJ, Yoo ID. Free radical scavenging and antielastase activities of flavonoids from the fruits of Thuja orientalis. Arch. Pharmacal Res. 2009;32(2):275-282.

7. Alabdul Magid A, Schmitt M, Prin PC, Pasquier L, Voutquenne-Nazabadioko L. In vitro tyrosinase inhibitory and antioxidant activities of extracts and constituents of Paeonia lactiflora Pall. flowers. Nat. Prod. J. 2017;7(3):237-245.

8. Schmitt M, Alabdul Magid A, Hubert J, Etique N, Duca L, Voutquenne-Nazabadioko L. Bio-guided isolation of new phenolic compounds from Hippocrepis emerus flowers and investigation of their antioxidant, tyrosinase and elastase inhibitory activities. Phytochem. Lett. 2020;35:28-36.

9. Piwowarski JP, Granica S, Kosinski M, Kiss AK. Secondary metabolites from roots of Geum urbanum L. Bioch. Syst. Ecol. 2014;53:46-50.

10. Blamey M, Grey-Wilson C. La flore d'Europe occidentale. Flammarion. 2003;544p. 
11. That QT, Thien TVN, Dang HP, Hoan NL, Vo LKT, Nguyen MHD, Ngu NT, Nguyen TS, Hansen PE. Chemical constituents of Geum urbanum L. roots. Nat. Prod. Res. 2018;32(21):2529-2534.

12. Cheng XR, Jin HZ, Qin JJ, Fu JJ, Zhang WD. Chemical constituents of plants from Genus Geum. Chem. Biodiversity. 2011;8(2):203-222.

13. Miladinovic DL, Ilic BS, Matejic JS, Randjelovic VN, Nikolic DM. Chemical composition of the essential oil of Geum coccineum. Chem. Nat. Comp. 2015;51(4):785786.

14. Panizzi L, Catalano S, Miarelli C, Cioni PL, Campeol E. In vitro antimicrobial activity of extracts and isolated constituents of Geum rivale. Phytother. Res. 2000;14(7):561-563.

15. Dimitrova L, Zaharieva MM, Kostadinova N, Tsvetkova I, Najdenski H, Popova M, Bankova V. Antimicrobial and antioxidant potential of different solvent extracts of the medicinal plant Geum urbanum L. Chem. Cent. J. 2017;11:113.

16. Granica S, Klebowska A, Kosinski M, Piwowarski JP, Dudek MK, Kazmierski S, Kiss AK. Effects of Geum urbanum L. root extracts and its constituents on polymorphonuclear leucocytes functions. Significance in periodontal diseases. J. Ethnopharmacol. 2016;188:1-12.

17. Gstirner F, Widenmann H. Contents of the rhizome of Geum urbanum. Sci. Pharm. 1964;32(2):98-104.

18. Khabibov ZK, Khalmatov KK. Phytochemical study of Geum urbanum and Geum rivale growing in Uzbekistan. Tashk. Gos. Med. Inst. 1972;68-70.

19. Hubert J, Nuzillard JM, Purson S, Hamzaoui M, Borie N, Reynaud R, Renault JH. Identification of natural metabolites in mixture: A pattern recognition strategy based on 13C NMR. Anal. Chem. 2014;86(6):2955-2962.

20. Maruenda H, Cabrera R, Canari-Chumpitaz C, Lopez JM. NMR-based metabolic study of fruits of Physalis peruviana L. grown in eight different Peruvian ecosystems. Food Chem. 2018;262:94-101.

21. Ni L, Liang W, Huang W, Chen J, Zou X, Li Y, Zou S. Chemical constituents of Euscaphis konishii and their inhibitory activities. Chem. Nat. Comp. 2019;55(5):832-834.

22. Shimomura H, Sashida Y, Adachi T. Phenolic glucosides from Prunus grayana. Phytochemistry. 1986;26(1):249-251. 
23. Johnson SR, Soprano SE, Wickham LM, Fitzgerald N, Edwards JC. Nuclear magnetic resonance and headspace solid-phase microextraction gas chromatography as complementary methods for the analysis of beer samples. Beverages. 2017;3(2):21.

24. Van QTT, Vien LT, Hanh TTH, Huong PTT, Thanh NV, Cuong NX, Nam NH, Minh CV. Triterpenoid derivatives from Barringtonia racemosa. Vietnam J. Chem. 2019;57(1):96-100.

25. Park SH, Oh SR, Ahn KS, Kim JG, Lee HK. Structure determination of a new lupanetype triterpene, tiarellic acid, isolated from Tiarella polyphylla. Arch. Pharm. Res. 2002;25(1):57-60.

26. Powder-George Y. Secondary metabolites from the leaves and stems of Leonotis nepetifolia (Lamiaceae). Trop. J. Nat. Prod. Res. 2018;2(6):293-296.

27. Abd El-Razek MH. NMR assignments of four catechin epimers. Asian J. Chem. 2007;19(6):4867-4872.

28. Yean MH, Kim JS, Hyun YJ, Hyun JW, Bae K, Kang SS. Terpenoids and phenolics from Geum japonicum. Saengyak Hakhoechi. 2012;43(2):107-121.

29. Comte G, Vercauteren J, Chulia AJ, Allais DP, Delage C. Phenylpropanoids from leaves of Juniperus phoenicea. Phytochemistry. 1997;45(8):1679-1682.

30. Spencer CM, Cai Y, Martin R, Lilley TH, Haslam E. The metabolism of gallic acid and hexahydroxydiophenic acid in higher plants. Part 4. Polyphenol interactions. Part 3. Spectroscopic and physical properties of esters of gallic acid and (S)hexahydroxydiphenic acid with Dglucopyranose (4C1). J. Chem. Soc. 1990;2(4):651-660.

31. Sritularak B, Boonplod N, Lipipun V, Likhitwitayawuid K. Chemical constituents of Canarium subulatum and their anti-herpetic and DPPH free radical scavenging properties. Rec. Nat. Prod. 2013;7(2):129-132.

32. Miyase T, Ueno A, Takizawa N, Kobayashi H, Oguchi H. Ionone and lignan glycosides from Epimedium diphyllum. Phytochemistry. 1989;28(12):3483-3485.

33. Yoshida T, Okuda T, Memon MU, Shingu T. Tannins of rosaceous medicinal plants. Part 2. Gemins A, B, and C, new dimeric ellagitannins from Geum japonicum. J. Chem. Soc. $1985 ; 1(2): 315-321$.

34. Ozden S, Durust N, Toki K, Saito N, Honda T. Acylated kaempferol glycosides from the flowers of Delphinium formosum. Phytochemistry. 1998;49(1):241-245.

35. Chang X, Li W, Jia Z, Satou T, Fushiya S, Koike K. Biologically active triterpenoid saponins from Ardisia japonica. J. Nat. Prod. 2007;70(2):179-187. 
36. Zhao XY, Wang G, Wang Y, Tian XG, Zhao JC, Huo XK, Sun CP, Feng L, Ning J, Wang C, Zhang BJ, Wang X. Chemical constituents from Alisma plantago-aquatica subsp. orientale (Sam.) Sam and their anti-inflammatory and antioxidant activities. Nat. Prod. Res. 2018;32(23):2749-2755.

37. Chen Y, Wang J, Ou Y, Chen H, Xiao S, Liu G, Cao Y, Huang Q. Cellular antioxidant activities of polyphenols isolated from Eucalyptus leaves (Eucalyptus grandis $\times$ Eucalyptus urophylla GL9). J. Funct. Foods. 2014;7:737-745.

38. Zavastin DE, Miron A, Gherman SP, Boerescu CM, Breaban IG, Gavrilescu CM. Antioxidant activity, total phenolic and metals contents of Lactarius salmonicolor (R. Heim \& Leclair). Farmacia. 2015;63(5):755-759.

39. Dutra RP, Abreu BVdB, Cunha MS, Batista MCA, Torres LMB, Nascimento FRF, Ribeiro MNS, Guerra RNM. Phenolic acids, hydrolyzable tannins, and antioxidant activity of geopropolis from the stingless bee Melipona fasciculata Smith. J. Agric. Food Chem. 2014;62(12):2549-2557.

40. Odontuya G. Anti-oxidative, acetylcholinesterase and pancreatic lipase inhibitory activities of compounds from Dasiphora fruticosa, Myricaria alopecuroides and Sedum hybridum. Mong. J. Chem. 2016;17(43):42-49.

41. Zhang YY, Zhang F, Thakur K, Ci AT, Wang H, Zhang JG, Wei ZJ. Effect of natural polyphenol on the oxidative stability of pecan oil. Food Chem. Toxicol. 2018;119:489495.

42. Qiao A, Wang Y, Xiang L, Zhang Z, He X. Triterpenoids of sour jujube show pronounced inhibitory effect on human tumor cells and antioxidant activity. Fitoterapia. 2014;98:137-142.

43. Xu J, Wang X, Su G, Yue J, Sun Y, Cao J, Zhang X, Zhao Y. The antioxidant and antihepatic fibrosis activities of acorns (Quercus liaotungensis) and their natural galloyl triterpenes. J. Funct. Foods. 2018;46:567-578.

44. Liu S, Zhu T, Qiu Y, Qi W, Wu H, Cai B, Lin J. Chromones and tannins from the fruit of Euscaphis japonica var. wupingensis. BioResources. 2019;14(3):5355-5364.

45. Shahani S, Monsef-Esfahani HR, Saeidnia S, Saniee P, Siavoshi F, Foroumadi A, Samadi N, Gohari AR. Anti-Helicobacter pylori activity of the methanolic extract of Geum iranicum and its main compounds. J. Biosci. 2012;67(3/4):172-180. 
46. Okuda T, Yoshida T, Hatano T, Iwasaki M, Kubo M, Orime T, Yoshizaki M, Naruhashi N. Tannins of Rosaceous plants. Part 11. Hydrolysable tannins as chemotaxonomic markers in the Rosaceae. Phytochemistry. 1992;31(9):3091-3096.

47. Aubert S, Choler P, Pratt J, Douzet R, Gout E, Bligny R. Methyl- $\beta$-D-glucopyranoside in higher plants: accumulation and intracellular localization in Geum montanum L. leaves and in model systems studied by ${ }^{13} \mathrm{C}$ nuclear magnetic resonance. J. Exp. Bot. 2004;55(406):2179-2189.

48. Ceylan R, Zengin G, Uysal S, Ilhan V, Aktumsek A, Kandemir A, Anwar F. GC-MS analysis and in vitro antioxidant and enzyme inhibitory activities of essential oil from aerial parts of endemic Thymus spathulifolius Hausskn. et Velen. J. Enzyme Inhib. Med. Chem. 2016;31(6):983-990.

49. Sartor L, Pezzato E, Dell'Aica I, Caniato R, Biggin S, Garbisa S. Inhibition of matrixproteases by polyphenols: chemical insights for anti-inflammatory and anti-invasion drug design. Biochem. Pharmacol. 2002;64(2):229-237. 


\section{Table 1}

Antioxidant and elastase inhibitory activities of extracts, fractions and compounds isolated from G. urbanum.

\begin{tabular}{|c|c|c|c|c|c|}
\hline & \multicolumn{2}{|c|}{ DPPH radical scavenging activity } & \multirow{2}{*}{$\begin{array}{l}\text { OH radical } \\
\text { scavenging } \\
\text { activity } \\
\mathrm{IC}_{50}(\mu \mathrm{g} / \mathrm{mL})\end{array}$} & \multirow{2}{*}{$\begin{array}{l}\text { Power cupric ion } \\
\text { reducing } \\
\text { (CUPRAC) } \\
\text { IC }_{50}(\mu \mathrm{g} / \mathrm{mL})\end{array}$} & \multirow{2}{*}{$\begin{array}{l}\text { Human } \\
\text { neutrophil } \\
\text { elastase inhibition } \\
\text { IC }_{50}(\mu \mathrm{g} / \mathrm{mL})\end{array}$} \\
\hline & $\mathrm{IC}_{50}(\mu \mathrm{g} / \mathrm{mL})$ & $\mathrm{IC}_{50}(\boldsymbol{\mu M})$ & & & \\
\hline GUM & $21.8 \pm 1.3$ & & $174.5 \pm 1.8$ & $1.5 \pm 0.1$ & $110.4 \pm 1.1$ \\
\hline DCMF & $(42 \%)^{\mathrm{a}}$ & & $188.3 \pm 3.5$ & $1.8 \pm 0$ & $17.6 \pm 1.1$ \\
\hline EAF & $14.7 \pm 0.8$ & & $142.7 \pm 5.7$ & $0.2 \pm 0$ & $6.0 \pm 1.1$ \\
\hline$n-B F$ & $<12.5$ & & $263.0 \pm 3.3$ & $0.5 \pm 0$ & $14.3 \pm 1.1$ \\
\hline $\mathbf{E A F}_{1}$ & $13.8 \pm 0.1$ & & $365.0 \pm 3.1$ & $4.8 \pm 0.3$ & $2.1 \pm 1.2$ \\
\hline $\mathbf{E A F}_{2}$ & $8.9 \pm 0.6$ & & $199.2 \pm 3.8$ & $2.9 \pm 0.1$ & $2.9 \pm 1.1$ \\
\hline $\mathbf{E A F}_{3}$ & $11.5 \pm 0$ & & $309.0 \pm 4.8$ & $2.3 \pm 0$ & $5.1 \pm 1.1$ \\
\hline $\mathbf{E A F}_{4}$ & $3.4 \pm 0.1$ & & $139.0 \pm 4.6$ & $3.0 \pm 0$ & $8.0 \pm 1.1$ \\
\hline $\mathbf{E A F}_{5}$ & $3.5 \pm 0.1$ & & $129.5 \pm 3.3$ & $1.8 \pm 0$ & $13.1 \pm 1.1$ \\
\hline EAF $_{6}$ & $3.0 \pm 0.1$ & & $131.5 \pm 0$ & $1.2 \pm 0$ & $11.9 \pm 1.1$ \\
\hline $\mathbf{E A F}_{7}$ & & & & & $12.2 \pm 1.2$ \\
\hline 2 & $22.6 \pm 2.2$ & $77.9 \pm 7.6$ & & & \\
\hline 3 & $28.5 \pm 0.8^{36}$ & $133.1 \pm 3.7^{36}$ & & & \\
\hline 4 & $47.8 \pm 3.1^{37}$ & $50.9 \pm 3.3^{37}$ & & & \\
\hline 5 & $20.1 \pm 0.4$ & $44.9 \pm 0.9$ & & & \\
\hline 6 & $18.5 \pm 0.2$ & $36.5 \pm 0.4$ & & & \\
\hline 7 & $5.0 \pm 0.3$ & $2.7 \pm 0.2$ & & & \\
\hline Quercetin ${ }^{b}$ & $5.4 \pm 0.2$ & $17.9 \pm 0.7$ & $52.2 \pm 4.8$ & $13.6 \pm 1.3$ & $6.0 \pm 0^{49}$ \\
\hline $\begin{array}{l}\text { Ascorbic } \\
\text { acid }^{b}\end{array}$ & $2.3 \pm 0.4$ & $13.1 \pm 2.3$ & $229.2 \pm 2.3$ & $13.3 \pm 0.5$ & \\
\hline Trolox $^{b}$ & & & & $5.4 \pm 0.3$ & \\
\hline
\end{tabular}

a \% Inhibition at $200 \mu \mathrm{g} / \mathrm{mL}$, b used as positive control. 


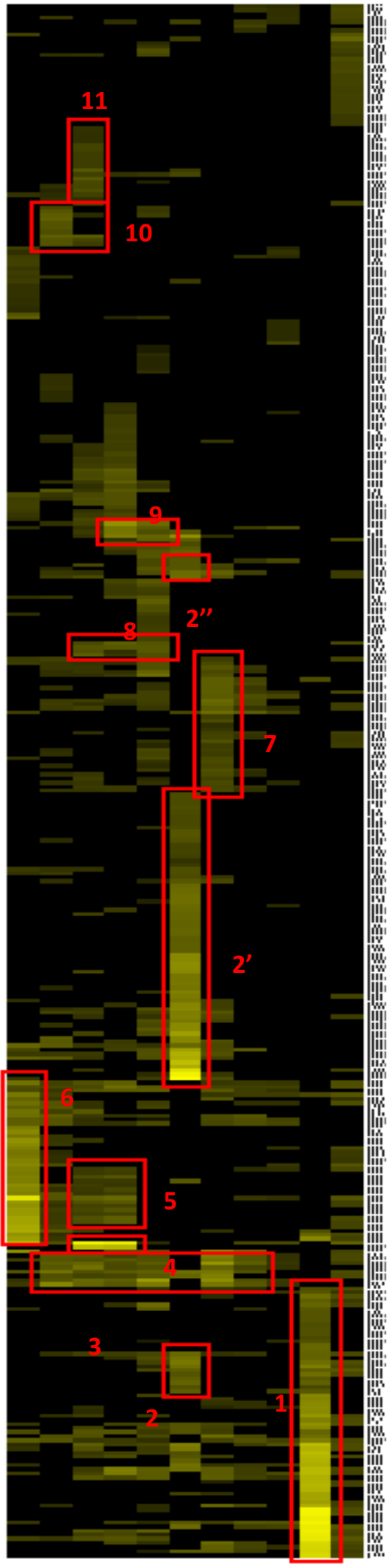<smiles>Oc1cc(O)c2c(c1)O[C@H](c1ccc(O)c(O)c1)[C@H](O)C2</smiles>

Cluster 8 : Ellagic acid pentoside<smiles>O=c1oc2c(O)c(OC3OCC(O)C(O)C3O)cc3c(=O)oc4c(O)c(O)cc1c4c23</smiles>

Cluster 6: Tormentic acid

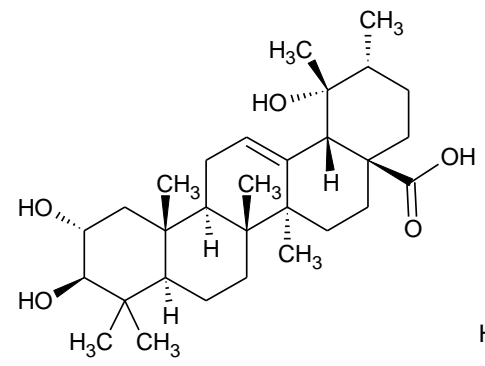

Cluster 4 : Succinic acid<smiles>O=C(O)CCC(=O)O</smiles>

Cluster 2': Gallic acid<smiles>O=C(O)c1cc(O)c(O)c(O)c1</smiles>

Cluster 2 + 2' + 2" :

Ellagic acid<smiles>O=C1OC2=C(O)C(O)=CC3C(=O)Oc4c(O)c(O)cc1c4C23</smiles>

Cluster 11: 3,3'-di-O-methylellagic acid<smiles>COC1=C2OC(=O)c3cc(O)c(OC)c4c3C2C(C=C1O)C(=O)O4</smiles>

Cluster 9: 3-(3,4-Dihydroxyphényl) propyl-glycosylated<smiles>Oc1ccc(CCCOP)cc1O</smiles>

Cluster 7: Caffeic acid<smiles>O=C(O)/C=C/c1ccc(O)c(O)c1</smiles>

Cluster 5 : Dotorioside II

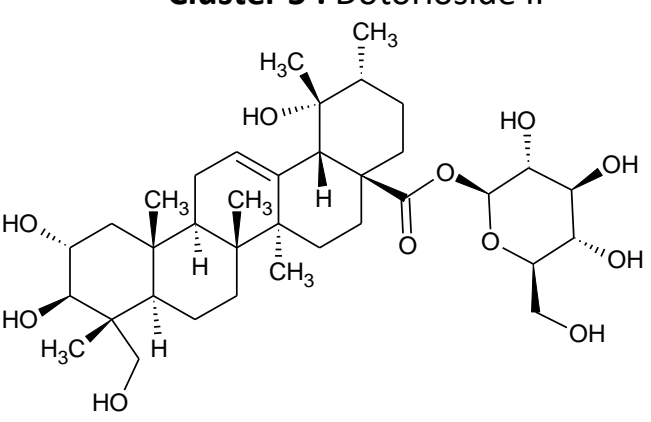

Cluster 3 + 7: 6 - $O$-trans-Caffeoyl- $\beta$-Dglucopyranoside + malic acid<smiles>O=C(O)CC(O)C(=O)O</smiles>

Cluster 1: Saccharose $+\beta$-D-Fructose<smiles>OCC1O[C@@H](O[C@@H]2O[C@H](CO)[C@H](O)[C@]2(O)CO)[C@H](O)[C@@H](O)[C@@H]1O</smiles><smiles>OC[C@H]1O[C@](O)(CO)[C@@H](O)[C@H]1O</smiles>

Fig. 1. ${ }^{13} \mathrm{C}$ NMR chemical shift clusters obtained by applying HCA on EAF CPC fractions from G. urbanum. 


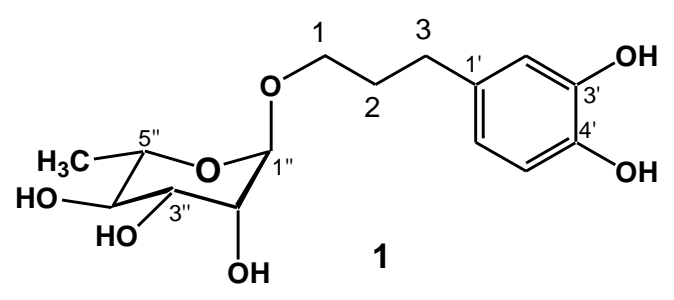

Fig. 2. Chemical structure of compound 1 isolated from G. urbanum aerial parts. 